\title{
EDITORIAL
}

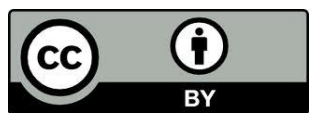

\section{DIREITO E RELIGIÃO}

Nesse primeiro volume de 2017 abrimos espaço para a seção temática que realiza uma primeira aproximação de vários subtemas no campo do Direito e Religião. O primeiro texto, escrito por W. de C. Bueno e M. R. Bertoldi, analisa a questão da laicidade do Estado no que tange as leis de liberdade religiosa e a relação com as retrições de práticas das religiões de Matriz Africana no Brasil. O segundo, aborda uma temática interessante, questiona a imparcialidade do Estado no que se refere ao registro das entidades religiosas no âmbito do Tribunal Europeu de Direitos Humanos, em especial o caso da Igreja Metropolitana de Bessarábia e outros da Moldávia de autoria de A. Fagundes. Na sequencia o texto de J. M. C. Motta e E. S. Neves discute os conceitos de ensino religioso e de orientação espiritual de crianças, adolescentes e jovens a partir de pesquisa introdutória no CEBUDV - Centro Espírita Beneficente União do Vegetal, também conhecida por UDV, União do Vegetal. O ultimo registro dessa seção é o trabalho de autoria de J. A. Rodrigues que versa sobre a questão do direito fundamental da liberdade religiosa no Brasil, sua definição e sua evolução como um dos primeiros direitos fundamentais.

Por fim, o texto de M. A. de A. Almeida e R. B. Dantas apresenta o Gnosticismo a partir da análise do Evangelho de Tomé e compõem a Seção de Artigos.

Boa leitura!

O Editor 